\title{
Surviving in General Management
}

\author{
A Resource for Health Professionals
}

\author{
Edited by \\ PAULINE FIELDING \\ PHILIP C. BERMAN
}

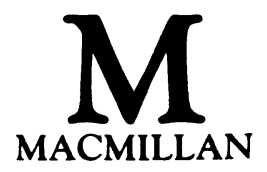


Individual chapters (C) The Contributors 1990

Collected volume (C) Pauline Fielding \& Philip C. Berman 1990

All rights reserved. No reproduction, copy or transmission of this publication may be made without written permission.

No paragraph of this publication may be reproduced, copied or transmitted save with written permission or in accordance with the provisions of the Copyright Act 1956 (as amended), or under the terms of any licence permitting limited copying issued by the Copyright Licensing Agency, 33-4 Alfred Place, London WC1E 7DP.

Any person who does any unauthorised act in relation to this publication may be liable to criminal prosecution and civil claims for damages.

First published 1990

Published by

MACMILLAN EDUCATION LTD

Houndmills, Basingstoke, Hampshire RG21 2XS

and London

Companies and representatives

throughout the world

Typeset by Footnote Graphics, Warminster, Wilts

British Library Cataloguing in Publication Data

Surviving in general management: a resource for health professionals.

1. Great Britain. Health services. Management

I. Fielding, Pauline II. Berman, Philip C.

362.1'068

ISBN 978-0-333-48314-5

DOI 10.1007/978-1-349-10599-1

ISBN 978-1-349-10599-1 (eBook) 


\section{Contents}

Acknowledgements

Notes on Contributors

iv

Preface

1 Planning Health Care Christine Hancock 1

2 Developing a Management Structure 21 Penny Humphris

3 Managing People Averil Dongworth 36

4 Making Use of Information Jolyon Vickers 50

5 Setting and Managing a Budget William Bryans 64

6 Managing Clinical Activity Josephine Plant 84

7 Managing the Quality of Care Alison Kitson 104

8 Disciplinary Action and Organisational 118 Consequences Trevor Ride

9 Staffing Matters Tom Keighley 129

10 Managing Industrial Relations Gordon Hemsley 143

11 Capital Planning and Commissioning Isobel Curry 157

12 Making Changes Happen Laurie McMahon with 172 Suzanne Goodband 


\section{Acknowledgements}

Many individuals have contributed to this book, some of them unwittingly. The case study material has been drawn from a variety of sources, based in the experience of the contributors and as a result of contact and discussion with a wide range of health service workers and clients. We are indebted to all of them and would like to record our thanks. 


\section{Notes on Contributors}

William J. Bryans, FCIS, FHSM, is area administrator for the Southern Health \& Social Services Board, Co. Armagh, Northern Ireland, and has a special responsibility for management and organisational development.

Isobel Curry, OBE, RGN, is estate development manager for the North West Thames Regional Health Authority, London.

Averil Dongworth, MBA, DN(Lond), RGN, is unit general manager at the Luton and Dunstable Hospital-Acute Services.

Suzanne Goodband, SRN, RSCN, RCNT, DN(Lond), is manager of children's services, Riverside Health Authority, London.

Christine Hancock, SRN, BSc(Econ), is general secretary of the Royal College of Nursing.

Gordon Hemsley, BA(Econ), MIPM, is district personnel manager, Parkside Health Authority, London.

Penny Humphris, BA, MSc(Econ), AHSM, is managing consultant with the Health Care Group, Peat, Marwick, McLintock.

Tom Keighley, RGN, RMN, NDNCert, RNT, DN(Lond), $\mathrm{BA}($ Hons), is director of nursing for the Waltham Forest Health Authority, Essex.

Dr Alison Kitson, DPhil, BSc(Hons), RGN, is RCN standards of care director and head, research and evaluation, Institute of Nursing, Radcliffe Infirmary, Oxford. 
vi Notes on Contributors

Laurie McMahon, BSc, MSc, is fellow in management \& organisational development at the King's Fund College, London.

Josephine Plant, BSc, RGN, RM, is chief nursing officer and director of service quality, Lewisham \& North Southwark Health Authority, London.

Trevor Ride, BA(Hons), RGN, RMN, IHSM(Inter), is assistant to the general secretary, Royal College of Nursing.

Jolyon Vickers, RSCN, RGN, ONC, Dip. in Health Information Service, is district information officer with Maidstone Health Authority, Kent. 


\section{Preface}

This book is intended to help those who have recently taken up managerial positions in health care. There is no shortage of books and articles which describe and analyse managerial roles in the National Health Service, but few of them are addressed more specifically to the newly appointed manager. As the title suggests, this volume is targetted at health professionals, and nurses in particular, who have made the move to general management, but its messages are equally applicable to new general managers from other backgrounds.

In the past twenty years, nurses, as managers, have come of age. Following the Salmon reorganisation, assistant matrons became 'nursing officers', shedding the purely administrative chores and taking up both clinical and managerial responsibilities. Their sphere of influence, however, was limited to nurses and nursing, and the potential of these nursing 'hybrids' was never fully realised, largely because of a lack of credibility as clinicians with their professional peers, and as real managers with health care administrators.

Changes within the nursing profession have enabled those nurses who wish to remain in practice to have a much longer clinical career 'at the bedside'. At the same time, the Griffiths reorganisation has considerably expanded the range of opportunities for nurses who are keen to assume wider managerial reponsibilities. Their functional background has prepared them well for this task and we believe that the experience and skills of ward sisters and community nurses will provide a fertile seedbed for the first line general managers of the future. Managers with a nursing background are ideally placed to regulate, coordinate and monitor the use of resources and to assess the outcomes of care. 
In designing this book, our purpose was to expose the reader to problems and issues that are likely to face most general managers. We felt that this could best be achieved by presenting each issue through a case study, which is then analysed and resolved, and from which some general conclusions are drawn. We also felt that, wherever possible, it would be appropriate to select authors who are practising managers and who are able to present the issues with a realistic flavour that comes from years of battle-scarred experience! This is, therefore, a practical book rather than an academic tome. We hope that it will be used by the manager, puzzling over the way to resolve some thorny managerial problem, who is seeking some fresh inspiration. At the point when he or she says, 'I wish I could talk to someone who has been through this problem', we hope that our manager will turn to the appropriate chapter for that helpful insight from an experienced manager which will provide the key to resolve the problem.

Management is not a neat or tidy business. While students may learn about information systems, budgeting or capital planning as nicely discrete subjects, the reality is that the boundaries between topics are ill-defined. This book has also been divided into apparently well-defined chapters, but readers will find that, as in reality, the subject matter of the chapters naturally overlap. We have arranged the chapters in three groups: the first group (Chapters 1-3) examines what might be called the macro-management issues of planning health care, developing a management structure and managing people. Within the context of these wider issues the second group (Chapters 4-11) looks at the more technical matters that face the general manager, while the final chapter considers how - with the body of knowledge and technical skills that the manager possesses - he or she can develop an approach which will make changes happen. It is not without significance that the final words of this book are 'common sense'.

The reader will probably not wish to read the book from beginning to end. Each chapter stands on its own - a resource to be used whenever the reader feels in need of 'external advice'. There is, however, a general pattern that runs through most of the chapters: a brief introduction, a case study followed by an analysis of the problems and solutions, concluding with some 
general principles. Many of the chapters use case studies with a nursing flavour, so that readers coming from a nursing background will feel familiar with the context of the case study. This should not, though, deter readers from other backgrounds, who will be able to apply the ideas even though the territory may not be their natural habitat.

We should like to extend a warm thanks to the contributors to this book who not only agreed to write on the subject that we requested, but also accepted that they should, in general terms, conform to the format that runs through the book. It is not easy to write within a pre-determined template, and the twelve authors have shown extraordinary patience with us.

Pauline Fielding

Philip C. Berman

1990 